University of Nebraska - Lincoln

DigitalCommons@University of Nebraska - Lincoln

Agronomy \& Horticulture -- Faculty Publications

Agronomy and Horticulture Department

$6-1983$

\title{
Quality Traits in Forage Sorghum Harvested at Early Head Emergence and at Physiological Maturity
}

\author{
Jeffrey F. Pedersen \\ University of Nebraska-Lincoln, jpedersen1@unl.edu \\ Francis A. Haskins \\ University of Nebraska-Lincoln, fhaskins@neb.rr.com
}

H. J. Gorz

Follow this and additional works at: https://digitalcommons.unl.edu/agronomyfacpub

Part of the Plant Sciences Commons

Pedersen, Jeffrey F.; Haskins, Francis A.; and Gorz, H. J., "Quality Traits in Forage Sorghum Harvested at Early Head Emergence and at Physiological Maturity" (1983). Agronomy \& Horticulture -- Faculty Publications. 304.

https://digitalcommons.unl.edu/agronomyfacpub/304

This Article is brought to you for free and open access by the Agronomy and Horticulture Department at DigitalCommons@University of Nebraska - Lincoln. It has been accepted for inclusion in Agronomy \& Horticulture -Faculty Publications by an authorized administrator of DigitalCommons@University of Nebraska - Lincoln. 


\section{QUALITY TRAITS IN FORAGE SORGHUM HARVESTED AT EARLY HEAD EMERGENCE AND AT PHYSIOLOGICAL MATURITY ${ }^{1}$}

\author{
J. F. Pedersen, F. A. Haskins, and H. J. Gorz ${ }^{2}$
}

\begin{abstract}
Information about the extent of variation in quality traits among plants sampled at the same developmental stage but on different dates would be useful to forage researchers. The primary purpose of this study was to obtain such information for five forage sorghum [Sorghum bicolor (L.) Moench] cultivars. Percent dry matter, crude protein, and in vitro dry matter disappearance of leaf, stem, and whole plant samples were determined for field-grown samples harvested on three different days during early head emergence (EHE) and once during physiological maturity (PM) for each cultivar. Orthogonal comparisons between EHE and PM sampling stages and among the EHE samples were made. Results of the 2-year study indicated that statistically significant differences existed among EHE samples and between EHE and PM samples. However, differences among EHE samples were generally much smaller than those between EHE and PM samples and may be of little importance for some applications.
\end{abstract}

Additional index words: Protein, Digestibility, Dry matter, IVDMD, Sorghum bicolor.

$\mathrm{D}$ IFFERENCES in quality traits of forage sorghum [Sorghum bicolor (L.) Moench] sampled at various stages of development or under different management regimes are well documented $(1,3,5,6,9)$. Much less information is available, however, on possible differences among plants of the same genotype and within the same field plot that reach a given developmental stage at different ages in terms c? days after planting. It would be useful for forage sorghum researchei. to know whether the quality traits of a plant that reaches a specific developmental stage on a certain day provide an accurate indication of the traits of other plants in the plot as they reach this stage several days later.

An easily identified stage in the development of forage sorghum is the end of the boot stage which is signaled by the beginning of head emergence. This study was designed to determine the extent of variation in percentages of dry matter, crude protein, and in vitro dry matter disappearance occurring among forage sorghum plants that reached early head emergence at different times after planting. Plants also were sampled at physiological maturity for comparison with the samples taken at head emergence.

\section{Materials and Methods}

Five forage sorghum cultivars ('Atlas', 'Brawley', 'Coleman', 'Early Hegari-Rox', and 'White Collier') were grown in 1976 and 1977 in a randomized complete block design with three replications at the University of Nebraska Agronomy Farm, Lincoln, Nebr.

\footnotetext{
${ }^{1}$ Contribution from the USDA-ARS, and the Dep. of Agronomy, Nebraska Agric. Exp. Stn., Lincoln. Published as Paper No. 6861, Journal Series, Nebraska Agric. Exp. Stn. Received 21 Apr. 1982.

2 Former graduate research assistant, Univ. of Nebraska, now assistant professor of agronomy, Auburn Univ.; George Holmes professor of agronomy; and supervisory research geneticist, USDA-ARS, and professor of agronomy, Univ. of Nebraska, Lincoln, NE 68583.

${ }^{3}$ Mention of a trademark or proprietary product does not constitute a guarantee or warranty of the product by the USDA or the Univ. of Nebraska, and does not imply its approval to the exclusion of other products that may also be suitable.
}

Each plot consisted of five $6.7-\mathrm{m}$ rows spaced $0.76 \mathrm{~m}$ apart. Planting dates were 5 May 1976 and 16 May 1977. An application of $112 \mathrm{~kg} \mathrm{~N} /$ ha was disked into the soil [Kennebec silt loam (Cumulic Hapludoll)] prior to each planting, and plantings were followed immediately by applications of a mixture of propachlor (2-chloro$N$-isopropylacetanilide) and atrazine [2-chloro-4-(ethylamino)-6(isopropylamino)-s-triazine] at 3.75 and $1.25 \mathrm{~kg}$ a.i./ha. To supplement rainfall, the plots were flood irrigated once, at about midsummer, both in 1976 and 1977.

The stage of early head emergence (EHE) was defined as occurring when the very tip of the head was first visible. When at least one culm in each row of a cultivar reached this stage, sampling of that cultivar was initiated. One culm at EHE was sampled from each row of the cultivar on sampling day one (EHE 1). Two and 4 days later, another single culm that had just reached the EHE stage was harvested from each row of the cultivar (EHE 2 and EHE 3, respectively). One set of samples also was taken for each cultivar at physiological maturity $(\mathrm{PM})$ as indicated by black layer formation (4).

The five culms harvested from a plot at each sampling day were cut off at the surface of the soil and were separated into leaf blade, stem plus leaf sheath, and head portions. Each culm was treated individually for assay. The immature head was considered to be part of the stem in all EHE samples. The separated samples were weighed and then dried at $75 \mathrm{C}$ in a forced draft oven to constant weight. Dried samples were ground in a Wiley ${ }^{3}$ mill to pass a 1$\mathrm{mm}$ screen, and subsamples were stored for subsequent analysis.

Percent crude protein (CP) was determined for each sample as Kjeldahl $\mathrm{N} \times 6.25(7)$, and in vitro dry matter disappearance (IVDMD) by a modification of the two-stage technique of Tilley and Terry (8). Percent dry matter (DM) was calculated for each sample, and values for CP, IVDMD, and DM were calculated for the total plant from the values for the leaf blade, stem, and, for PM samples, head portions.

Analysis of variance with orthogonal comparisons (2) was completed for each of the traits under study.

\section{Results and Discussion}

Mean squares for some of the sources of variation involved in this study are shown in Table 1. For many of the measured traits, statistically significant variations were associated with year interactions. Therefore, the mean squares are presented on an individual year basis. Inspection of these mean squares shows that significant differences were detected between the EHE and PM stages for all traits except total plant IVDMD in 1977, and that significant (EHE vs. PM) $\times$ cultivar interactions were found in all cases except total plant CP in 1976. Significant differences among the three EHE sampling dates were shown for most traits. However, the mean squares for variation among EHE samples were generally much smaller than those for EHE vs PM.

Means for each cultivar $X$ sample time $X$ year $X$ trait combination are shown in Table 2 . As expected, leaves and stems of all cultivars harvested at EHE were lower in DM than those harvested at PM. The difference between EHE and PM samples was especially pronounced for total plant values, reflecting the relatively high DM percentages of heads at the PM stage (separate data for heads not shown).

Decreases in forage CP and IVDMD are generally expected as plants advance in maturity. Comparison of CP values of leaves, stems, and total plants indicates that such a decrease occurred for all cultivars between EHE and PM. Similarly, leaves of all cultivars decreased in IVDMD between these two stages. However, Early Hegari-Rox was 
Table 1. Mean squares for selected sources of variation for three quality traits in five forage sorghum cultivars grown in 1976 and 1977 .

\begin{tabular}{|c|c|c|c|c|c|c|c|c|c|c|}
\hline \multirow[b]{3}{*}{ Source } & \multirow[b]{3}{*}{ df } & \multicolumn{9}{|c|}{ Trait } \\
\hline & & \multicolumn{3}{|c|}{ Dry matter } & \multicolumn{3}{|c|}{ Crude protein } & \multicolumn{3}{|c|}{ IVDMD } \\
\hline & & Leaf blade & Stem & Total plant & Leaf blade & Stem & Total plant & Leaf blade & Stem & Total plant \\
\hline \multicolumn{11}{|l|}{1976} \\
\hline 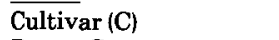 & 4 & $379.6^{*}$ & $370.9 *$ & $132.3^{*}$ & $110.4^{*}$ & $32.9^{*}$ & $114.3^{*}$ & $250.8^{*}$ & $922.1 *$ & $333.9^{*}$ \\
\hline $\operatorname{Rep} \times \mathrm{C}$ & 8 & 27.3 & 9.6 & 5.7 & 2.4 & 1.8 & 1.3 & 46.4 & 100.7 & 65.6 \\
\hline Sample (Spl) & 3 & $2513.5^{*}$ & 753.9* & $5001.7^{*}$ & $679.4^{*}$ & $156.5^{*}$ & $63.4^{*}$ & $447.0^{*}$ & $101.0^{*}$ & $96.6^{*}$ \\
\hline EHE vs PM† & 1 & $7540.1^{*}$ & $2188.9^{*}$ & $14975.2^{*}$ & $2017.8^{*}$ & $461.1^{*}$ & $177.9^{*}$ & $1303.3^{*}$ & $49.0^{*}$ & $160.8^{*}$ \\
\hline Among EHE & 2 & 0.2 & $36.4^{*}$ & $15.1^{*}$ & $10.2^{*}$ & $4.3^{*}$ & $6.1^{*}$ & $18.7^{*}$ & $127.0^{*}$ & $64.5^{*}$ \\
\hline $\mathrm{Spl} \times \mathrm{C}$ & 12 & $73.5^{*}$ & $35.9^{*}$ & $39.4^{*}$ & $9.6^{*}$ & $3.4^{*}$ & 1.6 & 8.2 & $77.7^{*}$ & $60.6^{*}$ \\
\hline (EHE vs PM) $\times$ C & 4 & $137.8^{*}$ & $79.0^{*}$ & $100.2^{*}$ & $21.6^{*}$ & $6.3^{*}$ & 2.1 & $16.5^{*}$ & $98.5^{*}$ & $122.9^{*}$ \\
\hline Among EHE $\times$ C & 8 & $41.3^{*}$ & 14.4 & $9.0^{*}$ & $3.6^{*}$ & $2.0^{*}$ & 1.4 & 4.1 & $67.3^{*}$ & $29.4^{*}$ \\
\hline Error & 267 & 15.9 & 8.3 & 4.1 & 1.8 & 0.9 & 1.0 & 4.7 & 10.2 & 5.9 \\
\hline \multicolumn{11}{|l|}{1977} \\
\hline$\overline{\text { Cultivar (C) }}$ & 4 & $59.8^{*}$ & $79.4^{*}$ & $52.6^{*}$ & $69.7^{*}$ & $17.1^{*}$ & $49.7^{*}$ & $394.9 *$ & $549.4 *$ & $425.5^{*}$ \\
\hline $\operatorname{Rep} \times \mathrm{C}$ & 8 & 7.5 & 9.2 & 4.4 & 1.5 & 1.1 & 0.9 & 60.5 & 83.6 & 76.9 \\
\hline Sample (Spl) & 3 & $192.4^{*}$ & $1,267.1^{*}$ & $5,450.0^{*}$ & $114.9 *$ & $173.5^{*}$ & $135.3^{*}$ & $352.5 *$ & $16.1^{*}$ & 12.5 \\
\hline EHE vs PM & 1 & $550.8^{*}$ & $3734.4^{*}$ & $16304.7^{*}$ & $343.5^{*}$ & $502.5^{*}$ & $385.7^{*}$ & $969.1 *$ & $30.6^{*}$ & 1.2 \\
\hline Among EHE & 2 & $13.2^{*}$ & 33.5* & $22.1^{*}$ & 0.6 & $9.0^{*}$ & $10.3^{*}$ & $44.2^{*}$ & 8.9 & $18.2^{*}$ \\
\hline Spl $\times$ C & 12 & $22.1^{*}$ & $33.5^{*}$ & 33.4* & $5.2^{*}$ & $1.4^{*}$ & $0.5^{*}$ & $26.1^{*}$ & $80.4^{*}$ & $31.7 *$ \\
\hline$($ EHE vs $P M) \times C$ & 4 & $27.5^{*}$ & $93.0^{*}$ & $89.7^{*}$ & $12.6^{*}$ & $3.4^{*}$ & $0.9^{*}$ & $70.0^{*}$ & $210.4^{*}$ & $74.3^{*}$ \\
\hline Among $\mathrm{EHE} \times \mathrm{C}$ & 8 & $19.4^{*}$ & $3.8^{*}$ & $5.2^{*}$ & $1.4^{*}$ & 0.4 & 0.4 & 4.2 & $18.8^{*}$ & 10.4 \\
\hline Error & 267 & 2.35 & 1.6 & 2.3 & 0.7 & 0.3 & 0.2 & 3.6 & 8.3 & 5.4 \\
\hline
\end{tabular}

* Significant at the 0.05 level.

$\dagger \mathrm{EHE}=$ Early Head Emergence, $\mathrm{PM}=$ Physiological Maturity.

Table 2. Means for three quality traits measured at four different times in five forage sorghum cultivars grown in 1976 and 1977.

\begin{tabular}{|c|c|c|c|c|c|c|c|c|c|c|c|}
\hline \multirow[b]{3}{*}{ Cultivar } & \multirow[b]{3}{*}{ Year } & \multirow[b]{3}{*}{ Sample } & \multicolumn{9}{|c|}{ Trait } \\
\hline & & & \multicolumn{3}{|c|}{ Dry matter } & \multicolumn{3}{|c|}{ Crude protein } & \multicolumn{3}{|c|}{ IVDMD } \\
\hline & & & Leaf blade & Stem & Total plant & Leaf blade & Stem & Total plant & Leaf blade & Stem & Total plant \\
\hline Atlas & 1977 & $\begin{array}{l}\text { EHE 1† } \\
\text { EHE } 2 \\
\text { EHE } 3 \\
\text { PM } \\
\text { EHE 1 } \\
\text { EHE } 2 \\
\text { EHE } 3 \\
\text { PM }\end{array}$ & $\begin{array}{l}22.7 \\
23.8 \\
24.1 \\
39.9 \\
21.9 \\
20.4 \\
23.8 \\
26.4\end{array}$ & $\begin{array}{l}14.9 \\
15.5 \\
15.7 \\
22.0 \\
13.6 \\
13.4 \\
14.8 \\
22.3\end{array}$ & $\begin{array}{l}17.0 \\
17.6 \\
17.6 \\
36.4 \\
15.8 \\
15.2 \\
17.1 \\
34.1\end{array}$ & $\begin{array}{r}16.6 \\
16.4 \\
16.1 \\
8.0 \\
17.9 \\
17.2 \\
17.5 \\
15.3\end{array}$ & $\begin{array}{l}\% \\
6.2 \\
5.6 \\
5.2 \\
2.5 \\
6.3 \\
6.2 \\
5.7 \\
2.9\end{array}$ & $\begin{array}{l}8.7 \\
8.2 \\
7.8 \\
6.0 \\
9.5 \\
9.2 \\
8.8 \\
6.2\end{array}$ & $\begin{array}{l}57.3 \\
56.3 \\
55.5 \\
50.1 \\
50.6 \\
50.3 \\
51.0 \\
44.8\end{array}$ & $\begin{array}{l}49.9 \\
58.0 \\
57.1 \\
55.6 \\
47.1 \\
45.0 \\
45.6 \\
48.2\end{array}$ & $\begin{array}{l}52.1 \\
57.6 \\
56.8 \\
61.6 \\
48.0 \\
46.2 \\
47.1 \\
48.9\end{array}$ \\
\hline Brawley & 1977 & $\begin{array}{l}\text { EHE 1 } \\
\text { EHE 2 } \\
\text { EHE } 3 \\
\text { PM } \\
\text { EHE } 1 \\
\text { EHE 2 } \\
\text { EHE } 3 \\
\text { PM }\end{array}$ & $\begin{array}{l}26.1 \\
27.2 \\
26.3 \\
40.1 \\
24.9 \\
25.6 \\
23.6 \\
26.1\end{array}$ & $\begin{array}{l}19.4 \\
20.2 \\
19.0 \\
29.0 \\
14.5 \\
15.4 \\
15.7 \\
25.9\end{array}$ & $\begin{array}{l}20.7 \\
21.9 \\
20.7 \\
34.8 \\
17.1 \\
17.8 \\
17.9 \\
33.1\end{array}$ & $\begin{array}{r}14.3 \\
13.5 \\
12.9 \\
8.8 \\
16.1 \\
16.1 \\
16.3 \\
13.9\end{array}$ & $\begin{array}{l}4.8 \\
4.4 \\
4.7 \\
2.6 \\
5.6 \\
5.4 \\
5.2 \\
2.9\end{array}$ & $\begin{array}{l}6.7 \\
6.2 \\
6.5 \\
4.7 \\
8.2 \\
7.9 \\
7.6 \\
5.5\end{array}$ & $\begin{array}{l}54.6 \\
54.0 \\
52.4 \\
48.6 \\
49.2 \\
47.9 \\
51.1 \\
47.6\end{array}$ & \begin{tabular}{l|}
63.4 \\
64.8 \\
65.0 \\
65.0 \\
51.3 \\
53.1 \\
53.8 \\
55.1
\end{tabular} & $\begin{array}{l}61.7 \\
62.4 \\
62.2 \\
60.9 \\
50.8 \\
51.8 \\
53.2 \\
52.7\end{array}$ \\
\hline Coleman & 1977 & $\begin{array}{l}\text { EHE 1 } \\
\text { EHE 2 } \\
\text { EHE } 3 \\
\text { PM } \\
\text { EHE 1 } \\
\text { EHE 2 } \\
\text { EHE } 3 \\
\text { PM }\end{array}$ & $\begin{array}{l}31.7 \\
26.7 \\
26.7 \\
35.7 \\
24.9 \\
24.1 \\
23.9 \\
26.0\end{array}$ & \begin{tabular}{l|}
17.5 \\
20.8 \\
18.6 \\
20.8 \\
13.4 \\
13.9 \\
14.6 \\
21.4
\end{tabular} & $\begin{array}{l}20.9 \\
22.0 \\
20.6 \\
34.8 \\
16.2 \\
16.4 \\
16.7 \\
33.3\end{array}$ & \begin{tabular}{r|}
13.6 \\
12.8 \\
12.5 \\
7.3 \\
15.4 \\
15.8 \\
15.4 \\
13.2
\end{tabular} & $\begin{array}{l}4.4 \\
4.6 \\
5.0 \\
2.1 \\
5.6 \\
5.2 \\
5.0 \\
2.4\end{array}$ & $\begin{array}{l}6.4 \\
6.1 \\
6.6 \\
5.4 \\
8.1 \\
7.9 \\
7.4 \\
5.5\end{array}$ & $\begin{array}{l}53.2 \\
53.0 \\
53.1 \\
49.0 \\
46.3 \\
45.4 \\
47.1 \\
42.3\end{array}$ & \begin{tabular}{l|}
62.1 \\
63.3 \\
63.9 \\
62.8 \\
47.3 \\
48.9 \\
49.1 \\
50.4
\end{tabular} & $\begin{array}{l}60.2 \\
61.3 \\
61.5 \\
59.1 \\
47.1 \\
48.3 \\
48.6 \\
45.9\end{array}$ \\
\hline $\begin{array}{l}\text { Early } \\
\text { Hegari-Rox }\end{array}$ & 1977 & $\begin{array}{l}\text { EHE } 1 \\
\text { EHE 2 } \\
\text { EHE } 3 \\
\text { PM } \\
\text { EHE } 1 \\
\text { EHE } 2 \\
\text { EHE } 3 \\
\text { PM }\end{array}$ & $\begin{array}{l}21.3 \\
22.4 \\
21.0 \\
31.5 \\
21.9 \\
22.1 \\
22.2 \\
25.2\end{array}$ & $\begin{array}{l}13.3 \\
13.6 \\
14.6 \\
20.0 \\
13.4 \\
13.9 \\
14.3 \\
17.5\end{array}$ & $\begin{array}{l}16.2 \\
16.6 \\
16.7 \\
36.9 \\
16.5 \\
16.9 \\
17.1 \\
38.0\end{array}$ & $\begin{array}{l}15.1 \\
16.1 \\
15.8 \\
10.3 \\
16.4 \\
15.7 \\
15.5 \\
11.7\end{array}$ & $\begin{array}{l}7.3 \\
6.9 \\
6.5 \\
2.9 \\
7.4 \\
6.8 \\
6.5 \\
3.0\end{array}$ & $\begin{array}{r}10.1 \\
10.0 \\
9.6 \\
8.1 \\
10.7 \\
9.9 \\
9.7 \\
7.4\end{array}$ & $\begin{array}{l}56.0 \\
55.9 \\
55.8 \\
50.3 \\
49.9 \\
48.8 \\
50.2 \\
42.3\end{array}$ & $\begin{array}{l}62.2 \\
60.8 \\
59.8 \\
54.7 \\
54.0 \\
53.2 \\
52.6 \\
46.4\end{array}$ & $\begin{array}{l}60.0 \\
59.2 \\
58.5 \\
61.3 \\
52.5 \\
51.6 \\
51.8 \\
48.4\end{array}$ \\
\hline $\begin{array}{l}\text { White } \\
\text { Collier }\end{array}$ & 1977 & $\begin{array}{l}\text { EHE 1 } \\
\text { EHE 2 } \\
\text { EHE } 3 \\
\text { PM } \\
\text { EHE } 1 \\
\text { EHE } 2 \\
\text { EHE } 3 \\
\text { PM }\end{array}$ & $\begin{array}{l}23.3 \\
24.8 \\
26.2 \\
35.7 \\
22.4 \\
20.6 \\
23.2 \\
27.0\end{array}$ & $\begin{array}{l}15.7 \\
17.2 \\
18.9 \\
24.2 \\
13.8 \\
13.0 \\
15.7 \\
24.8\end{array}$ & $\begin{array}{l}17.5 \\
18.9 \\
20.5 \\
34.3 \\
16.1 \\
15.1 \\
17.5 \\
29.8\end{array}$ & $\begin{array}{l}16.7 \\
16.2 \\
15.4 \\
10.0 \\
17.1 \\
17.3 \\
17.6 \\
16.1\end{array}$ & $\begin{array}{l}6.0 \\
5.1 \\
5.2 \\
2.8 \\
6.4 \\
6.3 \\
5.6 \\
3.5\end{array}$ & $\begin{array}{l}8.5 \\
7.6 \\
7.5 \\
5.9 \\
9.3 \\
9.3 \\
8.4 \\
6.2\end{array}$ & $\begin{array}{l}58.2 \\
58.3 \\
57.5 \\
54.9 \\
52.9 \\
52.4 \\
53.1 \\
51.0\end{array}$ & $\begin{array}{l}62.0 \\
63.2 \\
65.7 \\
64.3 \\
52.7 \\
51.3 \\
53.8 \\
56.4\end{array}$ & $\begin{array}{l}61.2 \\
62.1 \\
63.8 \\
65.8 \\
52.8 \\
51.7 \\
53.5 \\
55.1\end{array}$ \\
\hline
\end{tabular}

$\nmid \mathrm{EHE}=$ Early Head Emergence; 1, 2, and 3 refer to initial samples and samples harvested 2 and 4 days later, respectively. PM $=$ Physiological Maturity. 
the only cultivar for which stem IVDMD was substantially less at PM than at EHE. Because of this general lack of decline in stem IVDMD and the relatively high digestibility of the head at PM (not shown), differences in total plant IVDMD between EHE and PM were small.

Similarities in EHE and PM rankings are evident in the means shown in Table 2. However, $r$ values for the relationship of EHE and PM means were nonsignificant at the 0.05 probability level for all traits except total plant CP. In view of this fact, and of the numerous significant interactions of EHE vs. PM with both years (not shown), and cultivars (Table 1), it appears that EHE values were not reliable predictors of PM values for most traits. The presence of significant differences among EHE samples for most traits and the interaction of many of these with cultivars (Table 1) indicate that samples taken at different times as individual plants of a cultivar enter the EHE stage cannot be assumed to be the same. However, the small magnitude of the differences among EHE samples (Table 2) and the relatively small mean squares for variation among EHE samples (Table 1) suggest that in practice, samples that represent this growth stage adequately for many purposes may be harvested on different dates. This information should be useful to plant breeders, production researchers, and others to whom sample uniformity in forage sorghum is important.

\section{References}

1. Ademosum, A.A., B.R. Baumgardt, and J.M. Scholl. 1968. Evaluation of a sorghum-sudangrass hybrid at varying stages of maturity on the basis of intake, digestibility and chemical composition. J. Anim. Sci. 27:818-823.

2. Cochran, W.G., and G.M. Cox. 1957. Experimental Designs, 2nd ed. Wiley and Sons, Inc., New York.

3. Creel, R.J., and H.A. Fribourg. 1981. Interactions between forage sorghum cultivars and defoliation managements. Agron. J. 73:463-469.

4. Eastin, J.D., J.H. Hultquist, and C.Y. Sullivan. 1973. Physiologic maturity in grain sorghum. Crop Sci. 13:175-178.

5. Eilrich, G.L., R.C. Long, F.C. Stickler, and A.W. Pauli. 1964. Stage of maturity, plant population, and row width as factors affecting yield and chemical composition of Atlas forage sorghum. Kansas Agr. Exp. Stn. Tech. Bull. 138. 23 p.

6. Fribourg, H.A., B.N. Duck, and E.M. Culvahouse. 1976. Forage sorghum yield components and their in vivo digestibility. Agron. J. 68:361-365.

7. Horwitz, W., (ed.) 1960. Official Methods of Analyses of the Association of Official Agricultural Chemists, 9th ed. A. O. A. C., Washington, D. C.

8. Tilley, J.M.A., and R.A. Terry. 1963. A two-stage technique for the in vitro digestion of forage crops. J. Br. Grassl. Soc. 18:104-111.

9. Worker, G.F., and V.L. Marble. 1968. Comparison of growth stages of sorghum forage types as to yield and chemical composition. Agron. J. 60:669-672. 